\title{
FORESTRY EXTERNALITIES IN THE ENVIRONMENTAL MANAGEMENT ACCOUNTING SYSTEM
}

\author{
Miroslav Hájek, Karel Pulkrab \\ Czech University of Life Sciences Prague, Czech Republic \\ E-mail: hajek@fld.czu.cz, pulkrab@fld.czu.cz \\ Jaroslava Hyršlová \\ College of Economics and Management, Czech Republic \\ E-mail: jaroslava.hyrslova@vsem.cz
}

\begin{abstract}
Environmental management accounting is an environmental voluntary instrument, which is aimed at environmental and economic benefits. It is possible to apply environmental management accounting in different industry sectors. In case of forestry a challenging idea is to take into account all forestry externalities. It is important to try to find a solution to comprehend all forestry outputs into a system of environmental management accounting because externalities are often excluded and result is that managers do not have correct information for their decisionmaking. That is why it is important to know whether the accounting system includes externalities and how internalize all externalities. The problem is a methodology of assessing the externalities and willingness to allow externalities particularly in private enterprises. Assessment of externalities is not an invincible problem but a problem is to know what is their impact on enterprises and on society. A possibility to make a decision including externalities is what we want to solve. A lot of monetary and nonmonetary outputs exist in forestry. That is why we selected a forestry enterprise as an example.
\end{abstract}

Key words: environmental management accounting, externalities, internalization of externalities, forestry outputs, forestry externalities.

\section{Introduction}

Environmental management accounting is beneficial to various sectors, types of organizations and levels of management. It is a voluntary tool used largely in manufacturing enterprises, but also in public (state) enterprises. Environmental management accounting is one component of environmental management systems and tools for which many governments provide targeted support (OECD, 2007).

The concept adopted for practical application of environmental management accounting has been developed over the last 15 years (see for example, Gray, 1993, Schaltegger and Stinson, 1994, EPA, 1995, Gray et al., 1996, Schaltegger and Burittt, 2000). It is possible to start from the general definition that environmental accounting provides information on environmentally induced financial impacts on companies and on environmental aspects of the economic system (Schaltegger and Burritt, 2000). From this perspective the subject of environmental accounting can be viewed as representing environmentally imputed financial and environmental impacts. 
PROBLEMS

OF MANAGEMENT

IN THE $21^{\text {st }}$ CENTURY

Volume 5, 2012

\section{Problem of Research}

Environmental management accounting is a decision-making instrument which leads to economic and environmental benefits at the level of an enterprise. Practical results have confirmed that environmental management accounting helps towards a win-win solution for both the monetary and environmental aspects of the organisation. The aim is to improve the economy of organizations, their impact on the environment as well as establish social profitability as acknowledged by the notion of an organization internalizing its externalities. Because this is the way that environmental management accounting can be improved.

From the text above it is evident that environmental accounting has to be formed to provide the relevant users with the sufficient information and help the defined economic system improve its economic performance and environmental profile. Environmental accounting is a significant source of information for the enterprise management and for environmental management systems. It provides information which is the starting point for the identification of locations and operations burdening the environment and causing economic losses, and for the proposals of measures leading not only to the environmental profile improvements, but also the improvements of overall economic performance. Environmental accounting is a source of information to support decision-making, for example, in the area of strategy for reaching compliance with the environmental rules, regulations and standards, decision-making on investments, operating plant locations, waste management, risk management, cost (expenditure) management, etc.

According to the International Federation of Accountants, environmental management accounting is defined as environmental profile and economic performance management through the development and implementation of the corresponding environment-related accounting systems and procedures. Environmental management accounting can be defined as a system, which provides the information on environmentally caused financial impacts and on environmental aspects and impacts for the needs of particularly internal users.

\section{Research Focus}

The use of environmental management accounting is positively influenced by the level of mutual cooperation between people who have access to such data and the extent of interdependence in their activities and operations (Futagami, 2008). Hence, internalization of externalities is a matter for all cooperating enterprises, not just a matter for a single enterprise. Of great benefit is, for example, cooperation between forestry enterprises and consumers of forestry market and nonmarket outputs. Demand for wood processing and also municipalities and residents and others has influence on the effectiveness of forestry enterprises.

The article is focused on forestry outputs and their reflection in the system of environmental management accounting. The authors describe specific attributes of forestry and possible tracking. Important are possibilities how to use results of research in practise on the management level. In addition the article includes practical example and guideline how to use the proposed method. Environmental management accounting is a contemporary approach, which enable to reach a higher economic effectiveness and more efficient use of natural resources. That is why the research aiming is on the front burner. 
General Background of Research

Relevant elements of environmental management accounting include environmentally induced financial impacts on organizations as well as environmental aspects or impacts. Environmentally induced financial impacts represent the effect of organizational environmental behaviour on economic performance. In other words, this means impacts on costs, revenues, assets and liabilities that are caused by environmental actions of the given economic system ${ }^{1}$. Environmental aspects represent elements of operations, products or services, which may have an environmental effect. Environmental impact is any environmental change, favourable or adverse, which is fully or partly caused by operations, products or services.

Development of environmental management accounting has been influenced mainly by the information needs of interested parties. Environmental management accounting was gradually developed to provide environmental information relating to the defined economic system and designed to meet the information needs of the interested parties. Within environmental management accounting (see Figure 1), environmental information of both a monetary and non-monetary nature is gathered, recorded, evaluated and reported (Bennett and James, 1998, ECOMAC, 1996, IFAC, 1998, Schaltegger, Hahn and Burritt, 2001). Economic effects of acting on the environment (i.e. monetary information) are recorded in the accounts and people are held responsible for these effcets. This part of environmental management accounting can be considered as an extension and further elaboration (refining) of the scope of conventional accounting in response to current information needs. Information on environmental aspects and impacts expressed in physical units forms another important part of environmental accounting serving to meet information needs about the environmental profile of the defined economic system. From the viewpoint of users, environmental management accounting has to meet the needs of internal users and external stakeholders in a symbiotic relationship.

Methodology of a research is focused on definitions of the forestry externalities because forestry is a unique sector which produces a lot of positive externalities. In consequence of the special position of forestry comparison is used as a method how to modify and use the general model of environmental management accounting. Practical example shows how to handle externalities and their use in the system of environmental management accounting. On the basis of theoretical and practical approaches authors define recomendations.

\section{Sample of Research}

Private companies mostly monitor internal material flows and their behaviour towards ambient environment is based on generally set rules (legislation). On the other hand, environmental accounting of forestry enterprises also includes the monitoring of the forest stand in the given region. That is why it is possible to find substantial differences between forestry and other sectors. Reason is that forestry has a direct impact on the environment. The standing tree is both the factory and the final product (Klemperer 1996).

- Environmental management accounting (in physical units) is a basis for decisionmaking of internal users in the area of non-financial information. It focuses on the gathering, recording, evaluating and reporting of information needed for decisionmaking within the defined economic system (this primarily means the information on material and energy flows and forestry is as an example of renewable resources).

\footnotetext{
1 From the viewpoint of enterprise environmental accounting in this conception includes those environmentally caused financial impacts that are internalized, i.e. put to the account (or in favour) of the enterprise. Nevertheless, it has to be taken into consideration, that not all environmental effects of the organization are internalized. Forestry enterprises produce first of all positive externalities. Value of the positive externalities often exceed market output of forestry.
} 
PROBLEMS

OF MANAGEMENT

IN THE $21^{\text {st }}$ CENTURY

Volume 5,2012

- External environmental accounting focuses on the needs of external users in the area of non-financial information. External environmental accounting provides the information for external users, which are interested in environmental aspects and impacts (for example, the state authorities, the public, mass media, various groups and movements involved in environmental protection, etc.). It is the main source of information for external environmental reporting.

- Environmental accounting meeting the requirements in the area of non-financial information ensues from the environment-related laws and other regulations. The information is primarily intended for the state authorities (forestry regulatory bodies) for the purpose of checking compliance with the set and binding rules in forestry.

Environmental accounting in monetary units follows up with the expression in physical units. It is the essential part of environmental management accounting.

- Environmental management accounting in monetary units focuses on the financial information for internal users. It represents the main information tool and a basis for the major part of the decisions. This particularly includes the information on environmental costs, cost savings, and also may include the information on environmental revenues. Also externalities here can be expected to be figured out to a certain extent. Costs and revenues in forestry enterprises should comprise all costs and outputs (including nonmarket outputs).

- Environmental financial accounting is intended for meeting the needs of mainly external users in the area of financial information (for example, information on costs expended on environmental protection within a business or on the territory of a forestry enterprise, information on the generation and drawing of reserves associated with the environmental protection, information on the drawing from environmental fund, if established, etc.).

- Environmental accounting in monetary units meets the requirements in the area of financial information, ensuing from tax laws or other environment-related laws. This means specific information, which in certain countries is required by state administration bodies, banks, insurance companies, etc.

Further, it needs to be also mentioned that environmental management accounting may be applied in differing extent and may include:

- individual processes or groups of processes (for example, timber production),

- $\operatorname{system~(for~example,~forest~reproduction,~forest~conservation),~}$

- timber assortments,

- facility, operating plant or all facilities within a single site,

- regional or geographic groups of operating plants,

- the entire defined economic system (production market and non-market outputs in forestry).

It has already been mentioned, that environmental management accounting is divided into two subsystems - environmental management accounting in physical units = PEMA, and environmental management accounting in monetary units = MEMA. This approach within the environmental management accounting is used to demonstrate that emphasis is laid on the measurement of non-financial aspects of performance and on their management, which is of high importance mainly to long-term decision-making (Johnson and Kaplan, 1987, Kaplan and Norton, 1996). 
Miroslav HÁJEK, Karel PULKRAB, Jaroslava HYRŠLOVÁ. Forestry Externalities in the Environmental Management Accounting System

PEMA serves as information tool to support internal decision-making. The matter of \begin{tabular}{|l} 
PROBLEMS \\
OF MANAGEMENT \\
IN THE $21^{\text {st }}$ CENTURY \\
Volume 5,
\end{tabular} concern are environmental aspects and impacts, which are expressed in physical units. According to S. Schaltegger and R. Burrit (Schaltegger and Burritt, 2000), PEMA serves as

- an analytical tool allowing to identify strengths and weaknesses in the area of environmental approach,

- a tool to support decision-making processes, focusing on environmental quality assessment,

- a tool for the measurement of environmental efficiency,

- a tool allowing to perform both direct and indirect checks on environmental impacts,

- a responsibility tool providing a basis for internal (and indirectly also external) environmental communication,

- a tool which may help support sustainable development.

MEMA deals with environmental aspects which are expressed in monetary units. The matter of concern are, for example, costs of consumed materials, energies and water, costs of waste management, investments in projects mitigating environmental impacts, etc. MEMA represents a very significant tool to support internal decision-making processes - MEMA identifies, monitors and evaluates costs incurred and benefits (revenues, cost savings) gained in consequence of acting on the environment. The information resulting from MEMA is used within the strategic and tactical-operational planning, as information support for adopting measures to achieve the set objectives and target values. Such information also plays a significant role in responsibility management.

Environmental management accounting is very closely related to environmental management systems and environmental reporting (see Figure 1). These systems are common in forestry. Canadian Standard Association has a long time experience. Environmental management system is a management system to achieve an organization's environmental policies and objectives. Corporate policies and corporate culture reflecting sensitivity to an expanded accountability to stakeholders and a commitment to continuous improvement are the key to successful implementation (UN 1994).

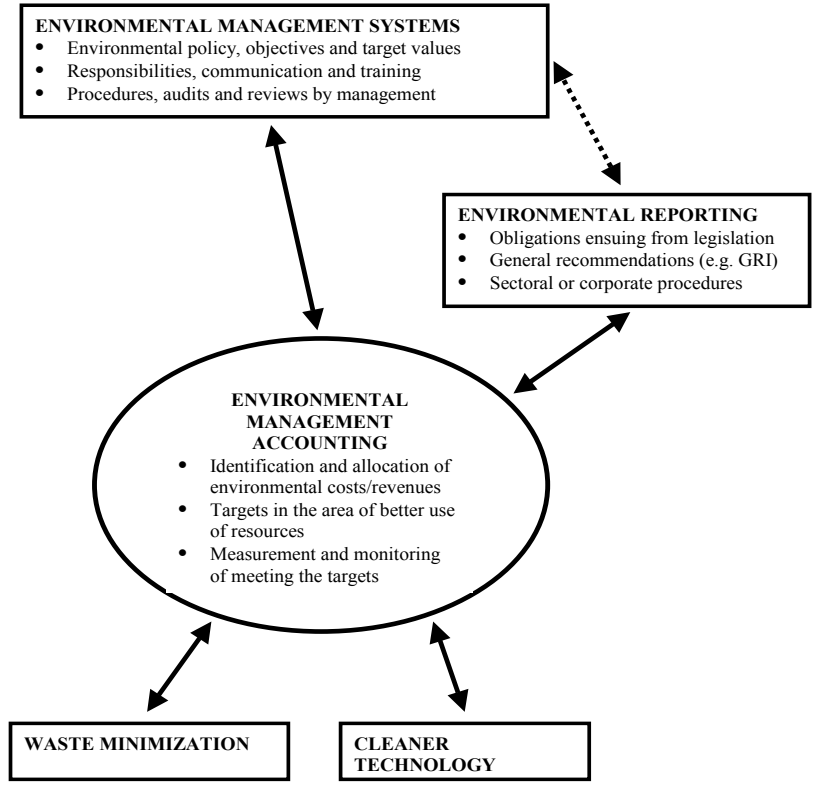

Figure 1: Environmental management accounting relation to environmental management systems and to environmental reporting. 
PROBLEMS

OF MANAGEMENT

IN THE $21^{\text {st }}$ CENTURY

volume 5, 2012

\section{Instrument and Procedures}

Implementation of environmental accounting consists particularly in tracking and evaluation of environmental costs. The need for tracking and management of environmental costs followed from an increase in the funds expended by the companies on environmental protection or in connection with environmental damage (Hyršlová and Sakál 2003). For companies in a number of industrial sectors, environmental costs have become a very important element of costs and the companies are beginning to pay increased attention to this aspect. The reasons, why the company management pays attention to the environmental performance and environmental costs could be summarized as follows:

- a number of environmental costs could be significantly reduced or even eliminated on the basis of correct business decisions - particularly through investment in cleaner technologies or product designs that are friendlier to the environment; a number of environmental costs (e.g. costs of waste management) add no value whatsoever to processes or products;

- environmental costs could be compensated by revenues (e.g. through a sale of byproducts, licences for cleaner technologies, etc.);

- improved environmental performance of the company can lead to cost savings; however, it has also other important benefits, e.g. for human health; improved environmental performance of the company increases the success of business;

- the understanding of environmental aspects and impacts of company activities and information on the environmental costs constitutes an important factor facilitating management with respect to the processes, departments (centres) and products, and forms a basis for the design of processes, products and services that are friendly to the environment;

- confirming the fact that company activities, products and services are friendly to the environment (i.e. that the company takes account of environmental impact of its activities, products and services, and attempts to improve its environmental performance), has the positive influence on the market position of the company. (Hyršlová, Hájek 2006)

A very frequent question is whether environmental management accounting includes all externalities. It is possible to say that environmental accounting does not include all externalities, but only those based on legislation. Other externalities are of no important effects on the environment. Legislation guarantees the internalization of externalities which is reflected in environmental management accounting. The internalization can theoretically take the form of legal requirements, market mechanisms or ethical pressure (Csutora, 2008).

The internalization of positive and negative externalities depends on environmental instruments and defining their parameters. The basic approach how to solve internalization has been developed in the four-decade history of environmental economics. Certain theoretical approaches to the creation of systems of practical environmental policies are known. For example, the Pigovian tax (Pigou 1932), which was applied later by many authors.

There are two main groups of economic tools that are used for internalization. The first one includes various types of environmental payments (charges, fees), which both send signals to polluters and create revenues that are allocated to an environmental protection fund. Financial contributions from the fund (subsidies, loans, etc.) that are used to support positive externalities form the second set of tools. It is important to stress that these two kinds of tools are linked up in a system of accounting. The economic instruments of both payments and financial contributions represent a special price of achieving a target quality of a natural resource (Šauer et al. 2003).

Emissions or services per unit are very often used as a basis for payments or subsidies. 
The payments or subsidies could also be derived from other sources such as the amount of goods that are produced or sold, or the amount of resources or energy used in the production process.

The amount of payments can be approximately proportional to the amount of negative externalities caused by polluters (it corresponds to a "polluter pays" principle), but it does not necessarily quantify these costs. The sum of the revenues from the payments can create the amount that is necessary for financial support of the pollution reduction or e.g. ecosystem services in line with the goals of environmental policy. Modified methods for assessing the efficiency of capital investments and a quantification of net costs of abatement serve as model bases to support decision-making of the polluters (Šauer et al. 2003).

Environmental accounting is a basis for consideration of efficiency and environmentally friendly behaviour. It is important to take into account all environmental costs (payments) and revenues (subsidies). In this case it is possible to state that environmental externalities are internalized. Private enterprises internalize the externalities according to the law (taxes, charges, emission limits, subsidies). It can be supposed that externalities which are not internalized, are not important for the environmental protection (Figure 2). It is possible to generalize that part of externalities are included in environmental management accounting.

A different situation is in public enterprises, because these enterprises are established not only to make profit, but also to meet society requirements. As a rule, public enterprises have worse operating results in comparison with the private ones because they often perform services (positive externalities) without payment. The final outcome is that public enterprises have higher environmental costs, but revenues are the same as in the case of the private ones (according to the law). It can be stated that public enterprises internalize the externalities (positive externalities) to a higher extent than the private ones, but at the expense of their profit (Figure 3).

Information system of enterprises

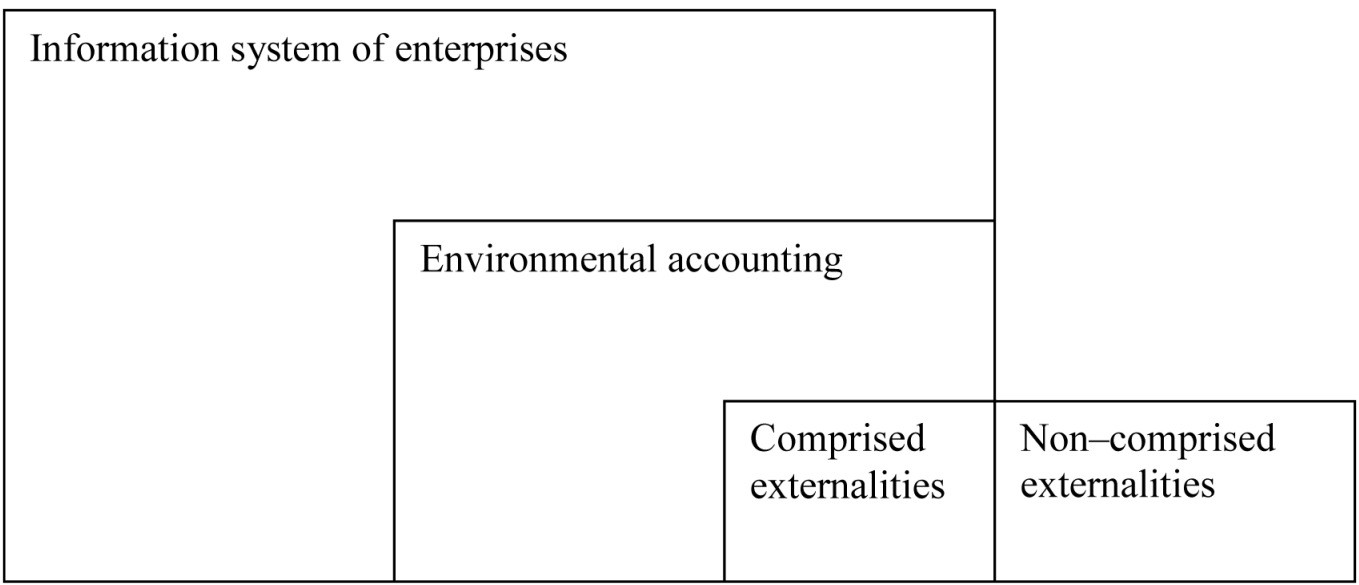

Figure 2: Internalized externalities in private enterprises. 


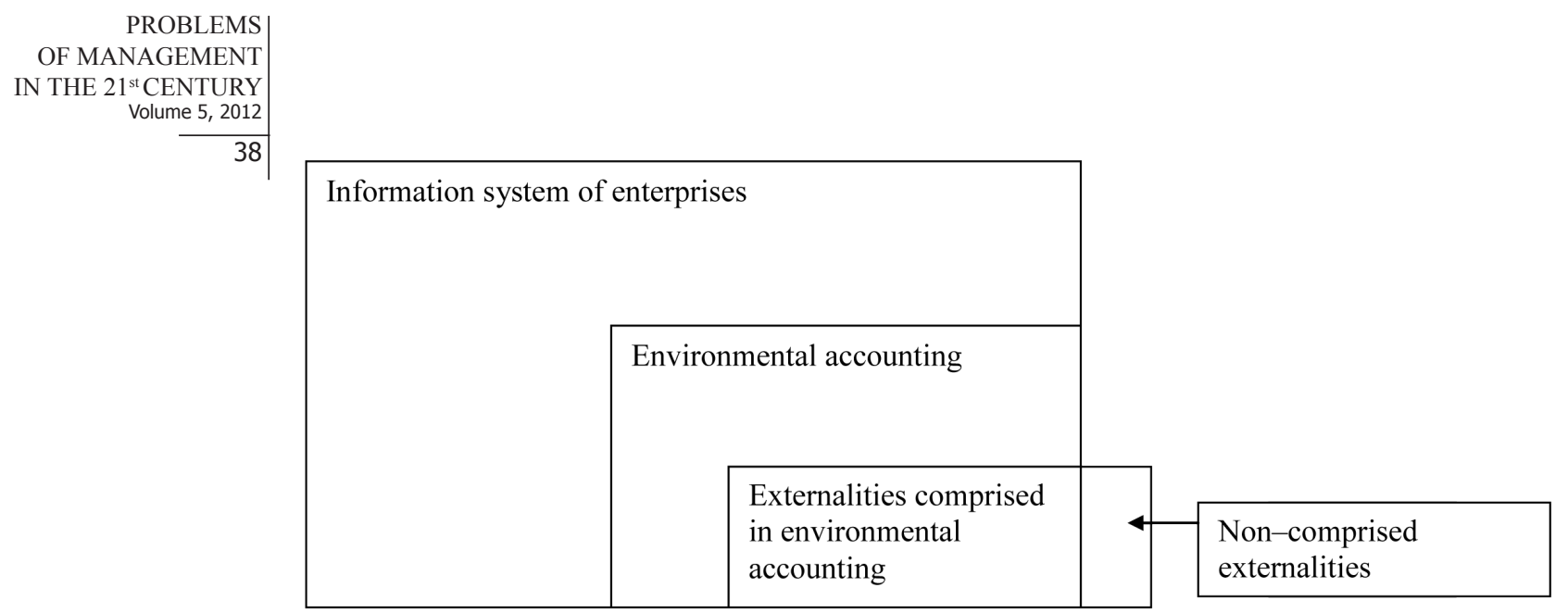

Figure 3: Internalized externalities in public enterprises.

\section{Results of Research and Discussion}

A forestry enterprise is an important territorial and ecosystem organization. From the viewpoint of organization type, a forestry enterprise can be characterized as a private or public corporation. Property rights take various forms in forestry. Numerous owner types can be found in this sector, such as state, corporation, individual, municipality, church, etc. Only some of these owners manage their own property directly.

A forestry enterprise has a significant influence on its territory. In legal relations, a forestry enterprise acts on its behalf and bears the responsibility ensuing from such relations. A forestry enterprise usually cares for overall development of the given territory needs, and in executing its tasks it also protects public interest. By course of law, forestry enterprises' sphere of competence includes the matters that are in the interest of society. Forestry enterprises produce a lot of different market as well as non-market outputs, for example market forest services (production functions, internalities) by incomes from commodities and services sales (timber production service, hunting and game management service), non-market forest services (externalities) with measurable market, economic, impacts (non-timber forest production services, soil-protective forest services, hydrological forest services, air protective forest services), non-market forest services (externalities) without measurable market impact (healthhygienic forest services, cultural-educational) (Šišák 2006).

Material and energy flow management is the basic approach in implementing the environmental management accounting. This tool aims to control the operations with regard to material, energy and information flows, so that the process runs efficiently and in conformity with the set targets. On the one hand, system of material flows is associated with added value generation, on the other hand, inseparable part of materials flows is formed by material losses incurred in the course of the individual (manufacturing) processes. It means that these are undesirable outputs, from both the economic and environmental viewpoints. This means that major attention starts to be paid to material flows, with emphasis being primarily laid on their transparency and the related costs.

In the forestry enterprise's view it is possible to use material and energy flow management but, certain differences exist in comparison to a manufacturing corporation. Forestry has the following particularities (Klemperer, 1996):

- forests have simultaneous outputs (e.g. if timber production service is supported nontimber forest production services are stimulated simultaneously) 
Miroslav HÁJEK, Karel PULKRAB, Jaroslava HYRŠLOVÁ. Forestry Externalities in the Environmental Management Accounting System

- harvesting can cause unpriced negative side effects

- clashes between public rights to certain natural amenities and private property rights

- if we look on wood production, the standing tree is both the factory and the final product (harvest the product, and much of the wood-producing mechanism is gone, although the soil and environment to start a new forest remain)

- forestry involves long production periods and uncertainty.

While none of the above are unique to forestry alone, together they form a special challenge in the profession (the role of market, prices, nonmonetary outputs).

Basic data for environmental management accounting are contained in inputs and outputs (Table 1), though the significance is quite different in comparison with a manufacturing enterprise. First, energy is the most important input. On the other hand, forestry produces a lot of different products, which may be called forest services. Forest services are differentiated by their diverse socio-economic essence and impact on the society, purpose of their employment in the society and input data availability. There were identified all basic forest services, generally differentiated by their socio-economic content (Šišák, Švihla, Šach, 2004):

market forest services

- timber production service

- hunting and game management service

- other market services

non-market environmental forest services

- with mediated market impact (with measurable market, i.e. economic, impacts)

○ non-wood forest production services

- soil-protective services (site soil erosion protection, protection against eroded soil deposits in water streams and reservoirs)

- hydrological (water management) forest services (protection against maximum runoffs and minimum runoffs in water streams, water quality in water streams, reservoirs and resources)

- air protective forest services (protection of air quality, climate, $\mathrm{CO}_{2}, \mathrm{NOx}$ capture)

- without measurable market impact

○ health-hygienic forest services (recreational and health influencing)

- cultural-educational (nature protective, educational, scientific and institutional) services.

Table 1. Environmentally significant inputs and outputs.

\begin{tabular}{|c|c|}
\hline INPUT in $\mathbf{k g}, \mathbf{G} \mathbf{J} /$ period & OUTPUT in $\mathrm{kg} /$ period \\
\hline Raw Materials & Product \\
\hline Auxiliary Materials & Waste \\
\hline Operating Materials & Waste Water \\
\hline Packaging & Air-Emissions \\
\hline Energy & \\
\hline Water & \\
\hline
\end{tabular}


PROBLEMS

OF MANAGEMENT

IN THE $21^{\text {st }}$ CENTURY

Volume 5, 2012

Thus, there are created basic conditions for proposing measures that are connected with significant material and cost savings. Material Flow Accounting and Material Flow Cost Accounting can also be used in the mapping of the situation in the area of handling of certain materials and in proposing measures which would contribute to the improvements in this area.

Furthermore, the information can be used in decision-making on environmental investments, i.e. on investments in environmental protection, and in environmental risk management. Important as well is internal and external reporting, because forestry enterprises or forest owners should inform the public about, for example, the status of the forestry in the region and about the goals and target values set for the forthcoming period according to forest management plan. This information is of concern also to the external interested parties. A proper form of reporting may significantly contribute to the improved perception of the forestry.

Besides material and energy flow, environmental management accounting includes accounting of environmental items. General structure (Table 2) contains also important items for forestry. For example, in the case of penalty as a result of soil erosion (negative externality) it is possible to use cell $1.6 \mathrm{~b}$, cleaner technologies for timber production cell $2.4 \mathrm{c}$. Services like ISO training courses, eco-audit etc. should be included in the item called "other" (d) and row 2.1 , because they usually apply to all of the domains simultaneously. Environmental revenues (5.) form an important part of the environmental accounting because of a number of non-market environmental forest services. The majority of these services represent positive externalities which are requested by society. That is why revenues are mostly in the form of subsidies.

Very important character of the non-market environmental forest services is that they are produced frequently in parallel with market forest services. On the other hand, demand for non-market services is higher and therefore society (government) supports higher production. The following alternatives may be experienced in practice:

- demand for non-market services is lower than supply of non-market services $\rightarrow$ there is no need to subsidize

- demand for non-market services is equal to supply of non-market services $\rightarrow$ there is no need to subsidize

- demand for non-market services is higher than supply of non-market services $\rightarrow$ it is necessary to subsidize.

For example, if it is necessary to increase $\mathrm{CO}_{2}$ capture: In this case the government supports longer rotation and compensates for financial loss or afforestation of nontimber land (it is possible to use cell 5.1 in Table 2). 
Table 2. Corporate environmental costs and revenues statement (proposal).

\begin{tabular}{|c|c|c|c|c|c|}
\hline Environmental domains & Air, climate & Soil & $\begin{array}{l}\text { Biodiversity, } \\
\text { landscape }\end{array}$ & Other & Etc. \\
\hline Environmental costs and revenues - category & a & $\mathrm{b}$ & C & $d$ & \\
\hline \multicolumn{6}{|l|}{ 1. Pollution treatment } \\
\hline \multicolumn{6}{|l|}{ 1.1 Depreciation } \\
\hline \multicolumn{6}{|l|}{ 1.2 Equipment maintenance } \\
\hline \multicolumn{6}{|l|}{ 1.3 Personnel } \\
\hline \multicolumn{6}{|l|}{ 1.4 External services } \\
\hline \multicolumn{6}{|l|}{ 1.5 Fees, taxes } \\
\hline 1.6 Fines, penalties and damages & & $\mathrm{x}$ & & & \\
\hline \multicolumn{6}{|l|}{1.7 Insurance for environmental liabilities } \\
\hline \multicolumn{6}{|l|}{1.8 Cleanup costs and remediation } \\
\hline \multicolumn{6}{|l|}{1.9 Other costs } \\
\hline \multicolumn{6}{|l|}{$\begin{array}{l}\text { 2. Pollution prevention and environmental man- } \\
\text { agement }\end{array}$} \\
\hline 2.1 External services & & & & $x$ & \\
\hline \multicolumn{6}{|l|}{ 2.2 Personnel } \\
\hline \multicolumn{6}{|l|}{ 2.3 Research and development } \\
\hline 2.4 Extra expenditures on cleaner technologies & & & $\mathrm{x}$ & & \\
\hline \multicolumn{6}{|l|}{2.5 Other costs } \\
\hline \multicolumn{6}{|l|}{ 3. Material purchase value of non-product output } \\
\hline \multicolumn{6}{|l|}{ 3.1 Raw materials } \\
\hline \multicolumn{6}{|l|}{ 3.2 Packaging } \\
\hline \multicolumn{6}{|l|}{ 3.3 Auxiliary materials } \\
\hline \multicolumn{6}{|l|}{ 3.4 Operating materials } \\
\hline \multicolumn{6}{|l|}{ 3.5 Energy } \\
\hline \multicolumn{6}{|l|}{ 3.6 Water } \\
\hline \multicolumn{6}{|l|}{ 4. Processing costs of non-product output } \\
\hline \multicolumn{6}{|l|}{ Total environmental costs } \\
\hline \multicolumn{6}{|l|}{ 5. Environmental revenues } \\
\hline 5.1 Subsidies, awards & $x$ & & & & \\
\hline \multicolumn{6}{|l|}{5.2 Other earnings } \\
\hline Total environmental revenues & & & & & \\
\hline
\end{tabular}

The goals of forestry enterprises are dependent on the type of ownership and on the goals of national forestry policy and its instruments. It depends on the interest, which social services are important for society. From this point of view, forest management is established. Nevertheless, achieving of the goals depends on the use of environmental management accounting and on a specific method of valuation of non-market environmental forest services.

Complete valuation of corporate activities is important because of proper decision making. If we look on forestry, as mentioned above, there is no problem to use the general methodology for environmental management accounting. It is important to use not only environmental costs, but for correct evaluation of the economic effects of corporate approach towards the environment, it is also necessary to concentrate on environmental revenues. Environmental revenues include, 
PROBLEMS

OF MANAGEMENT

IN THE $21^{\text {st }}$ CENTURY

Volume 5, 2012

42

e.g. revenues from recycling of materials, sales of wastes, subsidies (Hyršlová, Hájek, 2006). They

also include other revenue items, related to environmental cost items.

Subsidies support forestry outputs which are crucial for society. On the other hand, we have to know whether subsidies are efficient. That is why it is not only important to decide how much and how many non-market environmental forest services need to be subsidized. The efficiency analysis of the state support should be used (Hájek, 2000). For example, it is possible to use the formula for relative intensity ( $\mathrm{S}$ - subsidy, B - benefit of the supported non-market environmental forest service).

$$
R I=\frac{S}{B}
$$

Another possibility is to find optimal forestry production which desires the potential of all possible outputs. But it is unavoidable to value all outputs if we want to use these analyses.

One possibility how to value forestry outputs is shown in the following text. Valuation of market services is based on the average annual income from the respective markets (timber sale, hunting and game production). The valuation of hydrological forest services was done using costs of prevention, the valuation of soil protection services by costs of compensation, and the valuation of $\mathrm{CO}_{2}$ capture was done using shadow prices of carbon emission trade permits. The valuation of health-hygienic and cultural-scientific forest services of a non-market character was performed by expert approach using comparative method, i.e. comparing their socio-economic importance to the socio-economic importance of market services (timber production) (Šišák 2006). A possibility to use this methodology was tested at Forest Plant Židlochovice.

The Forest Plant Židlochovice administers 22.5 thousand ha of forests in an area important for different forest services, especially timber production forest service, hunting and game management, nature protection forest service, recreational forests, nature protection forest service (several important protected natural reserves from national and international point of view), and other services. Forest management can therefore be considered as typical multipurpose forest management in the Czech Republic.

It is possible to use results of valuation and calculations of socio-economic effectiveness of multipurpose forest management. The managerial staff of the Forest Plant Židlochovice together with the managerial staff of the state enterprise Forests of the Czech Republic can use these results for decision making in forest management. It is an example of a state-owned company, which wants to support all forest services (Figure 3).

The socio-economic values of individual forest services vary to a great extent by the respective forest site and forest stand, by environmental, social, cultural and economic factors in individual localities. Compared to average values and their fluctuation in conditions of the Czech Republic, the majority of services' values in the Forest Plant Židlochovice area are higher and the scope is more limited than in the territory of the Czech Republic. 
Table 3. Total socio-economic values of forest services in the whole area of Forest Plant Židlochovice (in EUR).

\begin{tabular}{|l|c|c|}
\hline Forest services & $\begin{array}{c}\text { Annual value } \\
\text { (EUR) }\end{array}$ & $\begin{array}{c}\text { Capitalized value } \\
\text { (EUR) }\end{array}$ \\
\hline Timber production & 6,256 & 312,816 \\
\hline Hunting and game management & 1,279 & 63,938 \\
\hline Non-timber production & 301 & 15,057 \\
\hline Hydrological - maximum runoffs & 54 & 2,718 \\
\hline Hydrological - minimum runoffs & 247 & 12,294 \\
\hline Hydrological - water quality in streams and reservoirs & 513 & 25,659 \\
\hline Soil protection - introskeleton site erosion & 11 & 530 \\
\hline Soil protection - soil deposits in streams, reservoirs & 0 & 6 \\
\hline Air protection - CO capture & 802 & 40,120 \\
\hline Health-hygienic & 3,069 & 153,421 \\
\hline Cultural-educational & 4,900 & 244,999 \\
\hline Total & 17,432 & 871,558 \\
\hline
\end{tabular}

Source: Šišák 2006.

As regards the whole forest area of the Forest Plant Židlochovice, most important is timber production service itself, which also involves the production of cultural-educational services (nature protection forest service) and health-hygienic services (recreational service) although benefits in the clasical accounting includes only timber production and hunting and game management. That is why two basic approaches are necessary. First solution is to introduce public financial support of all forest services (positive externalities), second solution is public ownership.

If the public support exists, forest services are realized, because financial support is included in the environmental revenues (Table 2). If the public support does not exist, the environmental revenues do not include financial support and private owners do not realize all forest services. On the other side public enterprises realize all services, because managers of public enterprises decide according valuation of forest services (example in the Table 3) and demands of society.

It is possible to summarize following findings

- use of the environmental management accounting system in forestry depends on internalization of forest externalities i.e. if externalities are not internalized they are not included in environmental management accounting

- possibility to use of the environmental management accounting system depends on the type of forest enterprise and on forest ownership

- private owners do not have an interest in valuation of this forest externalities which are not internalized

- public owners want to support generation of non-market forest services (externalities) and to analyze a value of their forests.

The problems which were solved in this article have broader concept because internalization of externalities depends on governments and their forestry strategies. If governments provide 
PROBLEMS

OF MANAGEMENT

IN THE $21^{\text {st }}$ CENTURY

Volume 5, 2012

internalization of all forestry externalities all forest owners have an interest in generation of non-market forest services. In this case environmental management accounting incorporates forest externalities completely and it is not possible to find differences between public and private forest owners.

\section{Conclusions}

Environmental management accounting is an important management instrument and also environmental policy instrument, which includes externalities point of view. There is a possibility to use the general methodology of the environmental management accounting system in forestry enterprises. Of great importance is the valuation of positive externalities in forestry. Forestry involves a lot of market and non-market outputs. That is why the valuation of all forestry outputs is important for decision making at the government level because of financial support and for public forestry enterprises.

This analysis proves possibility to use of the environmental management accounting system in forestry while the forestry externalities are internalized partially. On the other hand usually only public owners analyze and value all externalities (internalized or not) because of interest to cover society demand in the case of forestry. That is why governments have a key role in tracking and supporting positive forest externalities.

\section{References}

Accounting for Sustainable Forestry Management: A Case Study. (1994). United Nations conference on trade and Development, Geneva.

Bartolomeo, M., et al. (2000). Environmental Management in Europe: Current Practice and Further Potential. The European Accounting Review, 9 (1), 31-52.

Bennett, M., James, P. (1998). The Green Bottom Line. In Bennett, M. and James, P. (Eds.) Environmental Accounting for Management: Current Practice and Future Trends. The Green Bottom Line. Sheffield, Greenleaf Publishing.

Csutora, M. (2008). Measuring Tradeoffs between Sustainability Issues. In: Proceedings of the EMAN-EU Conference: Sustainability and Corporate Responsibility Accounting - Measuring and Managing Business Benefits. Corvinus University of Budapest.

Figge, F., Hahn, T., Schaltegger, S., Wagner, M. (2003). The Sustainability Balanced Scorecard as a Framework to Link Environmental Management Accounting with Strategic Management. In: Bennett, M., Rikhardsson, P., M., Schaltegger, S. (Editors), Environmental Management Accounting - Purpose and Progress. Dordrecht. Kluwer Academic Publishers.

Goddart, T. (2006). Do Social Objectives Integrate with Core Corporate Objectives? In: Schaltegger, S., Wagner, M. (Editors) Managing the Business Case for Sustainability. Sheffield, Greenleaf.

Gray, R. (1993). Accounting for the Environment. New York, Markus Weiner Publishing.

Gray, R. et al. (1996). Accounting and Accountability: Changes and Challenges in Corporate Social and Environmental Reporting. London, Prentice Hall Europe.

Hájek, M. (2000). Efektivnost výdajů z veřejných rozpočtů na ochranu životniho prostředí. Ústí nad Labem. Univerzita J.E. Purkyně.

Hájek, M. (2005). Possible Use of Analyses of Environmental Expenses of Territorial Budgets. Proceedings from International Conference 25 - 27 September 2005: Environmental Accounting Sustainable Development Indicators. Prague, Charles University in Prague.

Hyršlová, J., Hájek, M. (2006). Environmental Management Accounting in Czech Companies that Have Implemented Environmental Management Systems. In: Schaltegger S., Bennett M., Burritt R. (Editors), Sustainability Accounting and Reporting. Dordrecht, Springer.

Hyršlová, J., Sakál, P. (2003). Influence of Company Environmental Performance on Economic Results. In: Proceedings from the Conference of Slovak Technical University of Bratislava CO-MAT-TECH Trnava, Faculty of Materials Science and Technology in Trnava.

Klemperer, W. D. (1996). Forest Resource Economics and Finance. New York, McGraw-Hill, Inc. 
Miroslav HÁJEK, Karel PULKRAB, Jaroslava HYRŠLOVÁ. Forestry Externalities in the Environmental Management Accounting System

Jasch, Ch. (2001). Workbook 1, Environmental Management Accounting Metrics, Procedures and Principles. UN Division for Sustainable Development.

Johnson, H., Kaplan, R. (1987). Relevance Lost: The Rise and Fall of Management Accounting. Cambridge, Harvard Business School Press.

Kaplan, R., Norton, D. (1996). The Balanced Scorecard. Cambridge, Harvard Business School Press.

OECD (2007). Business and the Environment. Policy Incentives and Corporate Responses. OECD.

Pigou, A. C. (1932). The Economics of Welfare. London, Macmillan and Co.

Schaltegger, S., Burritt, R. 2000. Contemporary Environmental Accounting. Sheffield, Greenleaf Publishing.

Schaltegger, S., Stinson, C. (1994). Issues and Research Opportunities in Environmental Accounting (discussion paper 9124). Basel, Wirtschafts-wissenschaftliches Zentrum WWZ.

Schaltegger. S., Hahn, T., Burritt, R. (2001). Environmental Management Accounting - Overview and Main Approaches in Seifert E and Kreeb M (Eds.) Environmental Management Accounting and the Role of Information Systems. Sheffield, Greenleaf Publishing.

Šauer, P., Dvořák, A., Lisa, A., Fiala, P. (2003). A Procedure for Negotiating Pollution Reduction under Information Asymmentry. Environmental and Resource Economics, 24, 103-119.

Šišák, L., Švihla, V., Šach, F. (2002). Oceňováni společenské sociálně-ekonomické významnosti základnich funkci lesa (Pricing of socio-economic importance of basic forest services for the society). Prague, Ministry of Agriculture.

Šišák, L. (2004). Socio-economic valuation of forest services - case of the Czech Republic. Proceedings. International Conference: Economics of sustainable forest management. Toronto, University of Toronto.

Šišák, L. (2006). Forest services valuation system applied to forest plant Židlochovice of the forests of the Czech Republic state enterprise. In: International symposium on Managerial economics and accounting in an evolving paradigm of forest management. Rottenburg, University of applied forest sciences.

Advised by Jiři Hřebiícek, Mendel University in Brno, Czech Republic

Received: September 30, 2012

Accepted: November 24, 2012

OF MANAGEMENT

IN THE $21^{\text {st }}$ CENTURY

Volume 5, 2012

\footnotetext{
Received: September 30,2012
}

\author{
Accepted: November 24, 2012
}

\begin{tabular}{|ll|}
\hline Miroslav Hájek & Ph.D., Associate Professor, Czech University of Life Sciences Prague, \\
& Kamýcká 121, 16521 Prague, Czech Republic. \\
& E-mail: hajek@fld.czu.cz \\
& Website: http://www.czu.cz \\
\hline Karel Pulkrab & Ph.D., Professor, Czech University of Life Sciences Prague, Kamýcká 121, \\
& 165 21 Prague, Czech Republic. \\
& E-mail: pulkrab@fld.czu.cz \\
& Website: http://www.czu.cz \\
\hline Jaroslava Hyršlová & Ph.D., Associate Professor, College of Economics and Management, \\
Nárožní 2600/9a, 158 00 Prague, Czech Republic. \\
E-mail: jaroslava.hyrslova@vsem.cz \\
Website: http://www.vsem.cz
\end{tabular}

